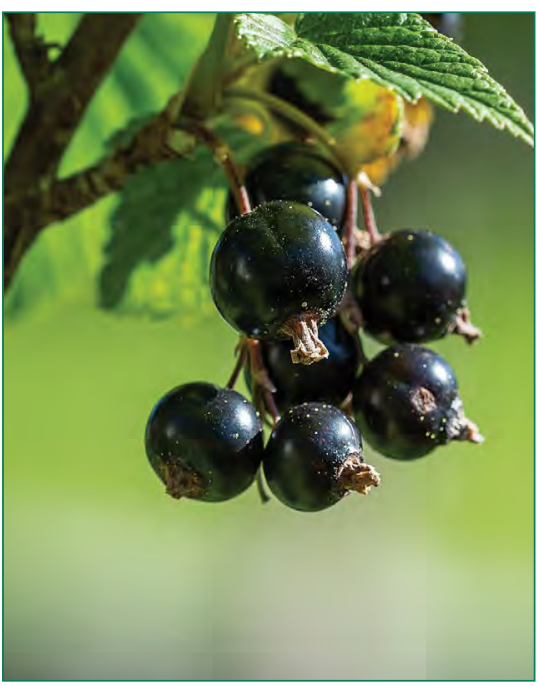

\title{
Blackcurrant (Ribes nigrum) - a true natural antioxidant
} Coacăzul negru (Ribes nigrum) un veritabil antioxidant natural

\author{
Cristina MUNTEANU \\ Medic rezident pediatrie, fitoterapeut și nutriționist \\ Departamentul Pediatrie, Universitatea de Medicină și Farmacie \\ "Victor Babeș", Timișoara
}

\begin{abstract}
Phytotherapy is the branch of alternative medicine that studies the treatment of various diseases with the help of plants and herbal preparations. One of the plants commonly used in phytotherapeutic treatments is blackcurrant. All its component parts are rich in active principles that are responsible for its phytotherapeutic properties. Numerous studies have approached the phytotherapeutic properties of blackcurrant. In this material we focused on researching data from the literature that include studies related to antioxidant action of blackcurrant.
\end{abstract}

Keywords: blackcurrant, Ribes nigrum, phytotherapy, antioxidant, anthocyanins, phenols

\section{REZUMAT}

Fitoterapia reprezintă acea ramură a medicinei alternative care se ocupă cu tratamentul diverselor afecțiuni cu ajutorul plantelor și al preparatelor din plante. Una dintre plantele utilizate frecvent în tratamentele fitoterapice este coacăzul negru. Toate părțile sale componente sunt bogate în principii active cărora li se datorează proprietățile sale fitoterapeutice. Numeroase studii au abordat proprietățile fitoterapeutice ale coacăzului negru. În acest material, ne-am oprit asupra cercetării datelor din literatură care cuprind studii legate de acțiunea antioxidantă a coacăzului negru.

Cuvinte cheie: coacăz negru, Ribes nigrum, fitoterapie, antioxidant, antocianine, fenoli

\section{INTRODUCERE}

Fitoterapia reprezintă acea ramură a medicinei alternative care se ocupă cu tratamentul diverselor afecțiuni cu ajutorul plantelor și al preparatelor din plante (1). Aceste preparate utilizează diferite părți componente ale plantelor (frunze, rădăcină, muguri, semințe, scoarță, flori) și pot fi regăsite sub diverse forme de prezentare, de la planta uscată pentru ceai la comprimate, capsule, extracte, tincturi, uleiuri vegetale și esențiale, vinuri, siropuri, unguente. 
Acțiunea plantelor se datorează compoziției lor chimice. Una dintre diferențele existente între un produs de sinteză și un produs fitoterapic este aceea că medicamentul conține, de regulă, o singură substanță activă, în timp ce o plantă conține numeroși compuși chimici. De exemplu, o plantă poate conține și până la 100.000-200.000 de metaboliți (2).

Una dintre plantele utilizate frecvent în tratamentele fitoterapice este coacăzul negru. Coacăzul negru (Ribes nigrum) este un arbust de cultură, originar din Tibet (3), cu o înălțime de 1-2 m. Tulpina arbustului de coacăz negru este nespinoasă, frunzele sunt formate din 3 lobi ascuțiți și dințați pe margini, florile se găsesc grupate în 5-10 raceme gălbui-roșietice, iar fructele sunt bace sferice negre, $\mathrm{cu}$ gust specific dulce-acrișor $(3,4)$. Toate componentele arbustului de coacăz negru sunt bogate în numeroase principii active, care îi conferă proprietățile

fitoterapeutice. Astfel, frunzele sale conțin flavonoizi, proantocianide, acid ascorbic, săruri minerale (4) ș.a. Fructele de coacăz negru sunt bogate în minerale (fier, calciu, fosfor, potasiu, sodiu, zinc, cupru), vitamine (carotenoide, $B_{1}, B_{2}, B_{6}, C$, PP), acizi organici (acid citric și malic), pigmenți antocianici, flavonoide $(4,5)$. Mugurii de coacăz negru sunt utilizați în gemoterapie, constituind o sursă bogată de enzime, vitamine, minerale, aminoacizi, fitohormoni, cu efecte regeneratoare și reglatoare asupra organismului (6). Semințele sunt bogate în acizi grași polinesaturați (PUFA), cu precădere acid gamalinolenic, alfa-linolenic și omega-6, fitosteroli, tocoferol $(4,7,8,9)$.

Datorită componenților activi enumerați, literatura citează coacăzul negru ca având un spectru larg de acțiuni: antioxidant (10), antiinflamator, antialergic $(11,12,13)$, antiaterosclerotic (4), antiviral $(14,15)$, antimicrobian $(15,16)$, vasodilatator și hipotensiv (3), protector ocular (17), diuretic (18); susține funcția digestivă și metabolismul (19), sistemul osteoarticular (20) și muscular (21), sistemul nervos (22) ș.a.

\section{OBIECTIVE}

Obiectivul cercetării de față l-a constituit identificarea a cât mai multe studii științifice și date din literatură care să dovedească proprietățile antioxidante ale coacăzului negru.

\section{MATERIAL SI METODĂ}

Am căutat articole și studii care să demonstreze proprietățile antioxidante ale coacăzului negru în bazele de date PubMed, ScienceDirect și Google Academic în anii 2005-2020. Am identificat astfel o paletă largă studii, efectuate atât in vivo, cât și in vitro. Am identificat studii care au avut ca subiect de cercetare coacăzul negru ca unic ingredient sau în combinații.

Nu am inclus în cercetarea noastră materialele care menționau generic doar Ribes spp., fără a fi făcută precizarea că este vorba și de coacăzul negru, existând mai multe specii de coacăz: alb (Ribes niveum), roșu (Ribes rubrum), auriu (Ribes aureum), agriș (Ribes uva-crispa) etc.

\section{REZULTATE ȘI DISCUTTII}

Efectul antioxidant al coacăzului negru este, de departe, cel mai explorat aspect al proprietăților fitoterapeutice ale acestei plante, din punctul de vedere al numeroșilor compuși antioxidanți $(23,24)$ din toate părțile sale componente. Fenolii (cu precădere 
antocianinele și flavonoidele) și acidul ascorbic sunt câteva din principiile active în care coacăzul este bogat reprezentat și cărora această plantă le datorează efectul său antioxidant.

Efectele antocianinelor și ale altor fenoli din coacăzul negru și o specie hibrid de zmeură ca inhibitori ai stresului oxidativ și ai deteriorării ADN-ului celular au constituit subiectul unui studiu publicat în anul 2006 (25). Studiul a demonstrat efectele protectoare ale extractelor din coacăz negru și specia hibrid asupra neuroblastomului uman și a celulelor promielocite expuse in vitro oxidării cu peroxid de hidrogen. Extractul fenolic din coacăzul negru a demonstrat cel mai mare efect protector împotriva neurotoxicității induse de peroxidul de hidrogen, a stresului oxidativ și a afectării ADN-ului celular.

Un studiu din anul 2007 (26) a examinat efectul sucurilor de portocale și de coacăze negre și a suplimentului de vitamina $\mathrm{E}$ asupra activității enzimei antioxidante paraoxonaza-1 (codificată la om de gena PON1) la pacienții cu boală arterială periferică. Concluzia studiului a fost aceea că prin consumul de suc de portocale și coacăz negru și suplimentul de vitamina E nu este influențată activitatea PON1 la pacienții cu boală arterială periferică.

Studiul următor (27), publicat în 2009 , este un studiu randomizat controlat; cercetarea nu a observat niciun efect al $\alpha$-tocoferolului asupra markerilor inflamatori sau ai celulelor endoteliale și concluzionează că numai doze foarte mari fiziologice de vitamina $E$ pot afecta inflamația. În acest studiu, sucul de portocală și coacăz negru a redus markerii de inflamație (proteina $\mathrm{C}$ reactivă și fibrinogenul) la pacienții cu boală arterială periferică.

Un alt studiu din anul 2009 (28) a evaluat efectul extractului de coacăze negre pe leziuni ale celulelor endoteliale vasculare (a venei ombilicale umane) induse de peroxid de hidrogen. Concluzia experimentului a fost că extractul de coacăz negru ar putea inhiba hipoxia indusă celulelor endoteliale, poate proteja celulele endoteliale umane din vena ombilicală deteriorate de peroxidul de hidrogen și poate scădea rata de apoptoză a acestor celule.

Tot din 2009, datează un studiu (29) care susține conceptul potrivit căruia consumul de antocianine de coacăz negru atenuează stresul oxidativ și poate, dacă este administrat la cantitatea și timpul adecvat, să completeze capacitatea de exercițiu pentru a spori gradul de reacție imună la potențialii agenți patogeni.

Un studiu comparativ, publicat în anul 2010 (30), a evaluat in vivo efectul antioxidant al coacăzului negru și al vitaminei E. Scopul acestui studiu a fost determinarea potențialului de scădere a stresului oxidativ al sucului de coacăz negru în comparație cu vitamina E. Stresul oxidativ a fost indus de aportul mare de acizi grași polinesaturați (PUFA) la porci. Aportul de suc din coacăz negru nu a redus formarea de malondialdehidă (indicator utilizat pentru a estima efectele stresului oxidativ asupra lipidelor), dar a prevenit eficient gradul de deteriorare a ADN-ului în leucocite, indus de aportul mare de PUFA. Concluzia acestui studiu a fost că, în aceste condiții experimentale, vitamina $E$ a fost mai eficientă ca antioxidant decât sucul de coacăz negru.
În 2010, un grup de cercetători a analizat (31) in vitro efectele antioxidante ale unor băuturi bogate în polifenoli precum sucul din rodie, coacăz negru, struguri, acai și vin roșu; de asemenea, a urmărit in vivo efectul consumului pe termen scurt de către persoane sănătoase asupra proprietăților antiaterogene. Studiul a demonstrat, pentru prima dată, faptul că sucul de rodie și cel de coacăz negru (și, într-o măsură mai mică, celelalte băuturi testate) consumate de subiecți sănătoși pe termen scurt au îmbunătățit proprietățile antiaterogenice serice și au crescut in vitro activitatea paraoxonază 1 (PON1) lactonază cu până la 51\%. În concluzie, sucurile bogate în polifenoli, cu proprietăți antioxidante in vitro impresionante, demonstrează, de asemenea, efecte antioxidante in vivo atunci când sunt analizate pentru consum pe termen scurt.

Un studiu din anul 2012 (32) a evaluat in vitro efectul protector al extractului din semințe de coacăze negre, roșii și albe asupra ADN-ului limfocitelor umane. Concluzia studiului oferă dovezi ale efectului protector al acestor extracte, numeroase din acțiuni fiind atribuite proprietăților antioxidante. Extractele din semințe de coacăze roșii și negre au prezentat un considerabil efect protector pe ADN-ul limfocitelor umane, chiar mai bun decât al antioxidanților sintetici și al agentului citoprotector utilizat în studiu.

Un alt studiu apărut în 2012 (33) relevă faptul că extractul din frunze de coacăz negru are cele mai mari capacități antioxidante și antiinflamatorii (inhibarea activității MPO și a producției de ROS pe neutrofile activate) corelate cu cel mai mare conținut total de fenoli. 
De asemenea, extractele de muguri au arătat un rol antioxidant semnificativ, comparativ cu extractele din fructe - frunzele și mugurii conțin de două ori mai mulți compuși fenolici. Concluzia studiului este aceea că extractele de coacăze negre au un puternic efect antioxidant, demonstrat de testele clasice in vitro, dar și de modele celulare, precum celulele endoteliale și neutrofilele polimorfonucleare.

Tot din anul 2012, datează un studiu (34) care analizează efectele sucului de coacăz negru asupra biomarkerilor legați de ateroscleroză în macrofage și concluzionează că acest suc a prezentat un puternic efect antiinflamator in vitro pe macrofage de cultură, probabil datorat concentrațiilor sale ridicate de polifenol și acid ascorbic.

Un studiu efectuat în anul 2013 (35)

a avut drept scop investigarea influenței sucului de coacăz negru asupra stresului oxidativ indus de etanol și consecințele sale asupra ficatului, creierului și serului șobolanilor. El a demonstrat că administrarea sucului de coacăz negru la șobolanii intoxicați cu etanol a exercitat un răspuns antioxidant prin refacerea nivelurilor de antioxidanți și a activității enzimatice și a prevenit efectele oxidante ale lipidelor și proteinelor. Valorile transaminazelor au revenit la normal după tratamentul cu coacăz negru la animalele cărora le-a fost administrat anterior etanol.

Un alt studiu, randomizat controlat, publicat în 2014 (36), a ajuns la concluzia că ingerarea sucului de coacăz negru bogat în vitamina C și polifenoli poate scădea stresul oxidativ și poate îmbunătăți sănătatea vasculară la persoanele cu un aport alimentar redus de fructe și legume.

O cercetare din 2014 (37) a avut drept scop determinarea compoziției chimice (antocianină, acid ascorbic, fenoli și taninuri) și a activității antioxidante și antimicrobiene a sucurilor și extractelor din patru varietăți de coacăz negru. Efectul antioxidant a fost pus în strânsă corelație cu conținutul fenolic al speciilor investigate. Sucurile și extractele de coacăz negru testate în cadrul acestui studiu au prezentat activitate antimicrobiană împotriva unui panel de microorganisme, cele mai sensibile tulpini în acest sens fiind $L$. monocytogenes și $P$. aeruginosa.

Am identificat un studiu (38), tot din 2014, care analizează efectele extractelor de coacăz negru asupra celulelor limfoblastoide umane TK6 și a deteriorării ADN-ului indusă de peroxidul de hidrogen. Rezultatele studiului concluzionează că tratamentul cu extracte de coacăz negru poate reduce instabilitatea genomică indusă de peroxidul de hidrogen în celulele umane, aceste efecte antigenotoxice fiind legate de polifenoli, acid ascorbic și alți compuși antioxidanți.

Un alt material din 2014 (39) analizează activitatea extractelor de coacăze negre în raport cu membranele eritrocitare, concluzia studiului fiind aceea că extractele au o activitate antioxidantă ridicată și că prezența lor pe suprafața membranei eritrocitare atrage protecția împotriva radicalilor liberi.

Din 2014, datează un studiu (40) care analizează efectele fructelor de pădure, între care și coacăza neagră, asupra macrofagelor. Concluzia cercetării este aceea că antocianinele din fructele de pădure suprimă expresia și secreția mediatorilor proinflamatori din macrofage prin inhibarea translocării nucleare a NF-kB independent de mecanismul mediat de NRF2.

Următorul material este un studiu din 2017 (41), care a avut drept scop să explice modul în care extractele din aronia și coacăz negru interacționează cu faza lipidică a membranei biologice și cu albumina umană. Rezultatele experimentului au concluzionat că extractele din aronia și coacăz

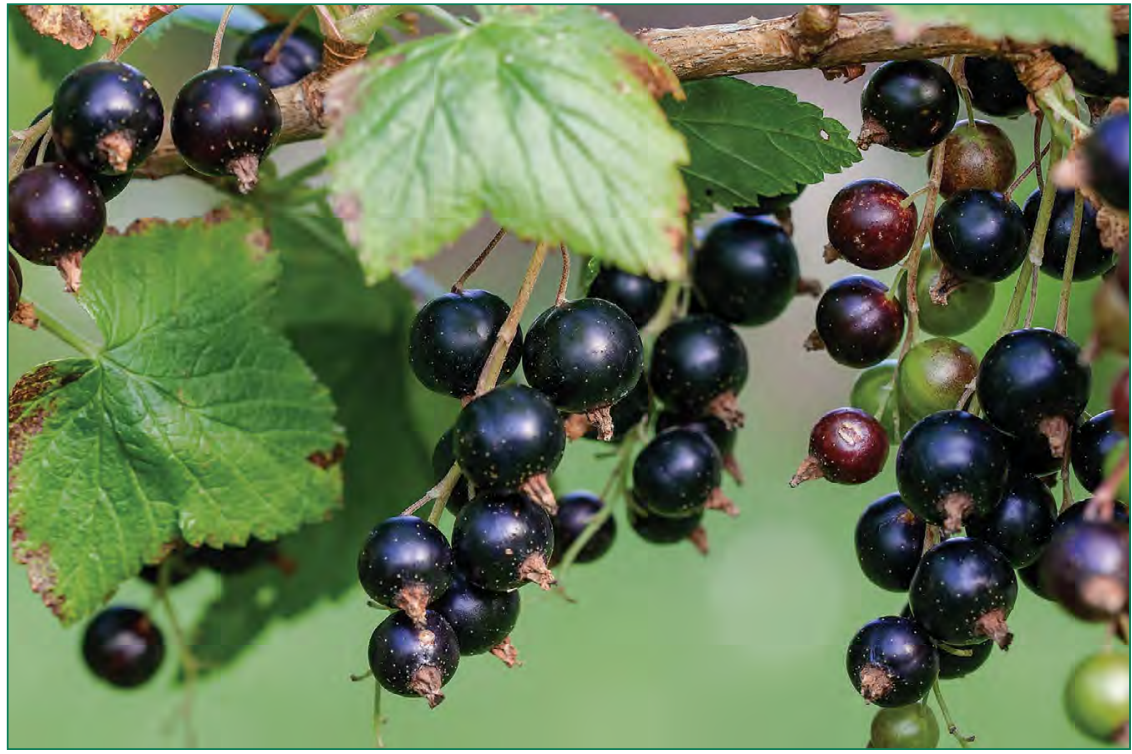


negru și derivații lor de cianidină prezintă o activitate antioxidantă ridicată, care protejează membrana lipidică de radicalii liberi.

Un alt studiu, datând din 2017 (42), evaluează in vitro activitatea radioprotectoare a extractului de coacăz negru. Descoperirile realizate în urma cercetării susțin în mod evident potențialul de apărare al genomului de coacăz negru împotriva leziunilor ADN-ului indus de radiațiile gama; aceste activități de apărare a genomului sunt legate de compușii antioxidanți din coacăze negre.

O cercetare publicată în anul 2018 (43) evaluează rolul coacăzului negru (Ribes nigrum) în expunerea celulelor fibroblaste dermice umane la radiațiile UVB care induce producția de specii reactive de oxigen (ROS). Rezultatele acestui studiu au demonstrat că Ribes nigrum scade ROS și reduce generarea de IL-6 indusă de UVB în celulele NHDF. Aceste descoperiri sugerează că Ribes nigrum este un potențial agent antiîmbătrânire.

Ultimul studiu pe care îl cităm datează din 2019 (44); el a urmărit comparativ extractele de coacăz negru, aronia, afin siberian (Lonicera caerulea) și revent (Rheum rhaponticum) privind activitatea lor antioxidantă și antimicrobiană. Cea mai puternică inhibare a creșterii bacteriene a fost observată în rădăcinile de culoare închisă ale reventului, iar aronia, afinul siberian și coacăzul negru au avut cea mai puternică activitate antioxidantă.

Trebuie să ținem cont de faptul că în compoziția coacăzului există numeroase substanțe cu efect antioxidant și că vorbim de o acțiune sinergică a acestor substanțe, iar acest conținut este și el direct influențat de numeroși factori precum partea din plantă utilizată, condițiile climatice în perioada dezvoltării, timpul de recoltare, modul de procesare $(45,46)$ etc.
CONCLUZII

Studiile numeroase identificate în perioada 2005-2020 au scos în evidență preocuparea pentru proprietățile coacăzului negru în general și pentru cea antioxidantă în special. Am identificat o gamă largă de studii, vizând coacăzul negru singur sau în asociere cu alte plante, studii efectuate in vitro sau in vivo, pe animale sau pe oameni, urmărind obiective diverse, de la cele terapeutice la cele legate de industria alimentară.

Majoritatea studiilor concluzionează că există o acțiune antioxidantă a coacăzului negru. Efectul antioxidant se datorează în principal fenolilor, dintre care se remarcă antocianinele și flavonoidele. Considerăm necesară efectuarea mai multor studii clinice - și chiar reluarea unor studii anterioare - pentru a putea înțelege mecanismele prin care acționează substanțele active din coacăzul negru.

Conflict of interest: none declared Financial support: none declared

currant (Ribes nigrum L.) on atopic dermatitis in NC/Nga mice. Biosci Microbiota Food Health. 2018;37(1):19-24

12. Sgouros D, Katoulis A, Rigopoulos D. Novel topical agent containing superoxide dismutase $100,000 \mathrm{IU}$ and $4 \%$ of plant extracts as a mono-therapy for atopic dermatitis. J Cosmet Dermatol. 2018;17(6):1069-1072.

13. Nyanhanda T, Gould EM, McGhie T. Blackcurrant cultivar polyphenolic extracts suppress CCL26 secretion from alveolar epithelial cells. Food Funct. 2014; 5(4):671-7.

14. Knox Y M, Hayashi K, Suzutani T et al. Activity of anthocyanins from fruit extract of Ribes nigrum L. against influenza $A$ and $B$ viruses. Acta Virol. 2001;45(4):209-15.

15. Ikuta K, Hashimoto K, Kaneko $\mathrm{H}$ et al. Anti-viral and anti-bacterial activities of an 
extract of blackcurrants (Ribes nigrum L.). Microbiol Immunol. 2012;56(12):805-809.

16. Đorđević BS, Pljevljakušić DS, Šavikin KP et al. Essential Oil from Blackcurrant Buds as Chemotaxonomy Marker and Antimicrobial Agent. Chemistry\&Biodiversity. 2014;11(8):1228-1240.

17. Matsumoto H, Nakamura Y, Tachibanaki S et al. Stimulatory effect of cyanidin 3-glycosides on the regeneration of rhodopsin. J Agric Food Chem. 2003;51(12):3560-3563.

18. Valnet J. Fitoterapia. Tratamentul bolilor $\mathrm{cu}$ plante. București: Ed. Garamond, 2003:95.

19. Park JH, Kho MC, Kim HY et al. Blackcurrant Suppresses Metabolic Syndrome Induced by High-Fructose Diet in Rats. Evid Based Complement Alternat Med. 2015;2015:385976.

20. Garbacki N, Angenot L, Bassleer C et al. Effects of prodelphinidins isolated from Ribes nigrum on chondrocyte metabolism and COX activity. Naunyn Schmiedebergs Arch Pharmacol. 2002;365(6):434-41.

21. Matsumoto H, Takenami E, IwasakiKurashige $\mathrm{K}$ et al. Effects of blackcurrant anthocyanin intake on peripheral muscle circulation during typing work in humans. Eur J Appl Physiol. 2005;94(1-2):36-45.

22. Watson AW, Okello EJ, Brooker HJ et al. The impact of blackcurrant juice on attention, mood and brain wave spectral activity in young healthy volunteers. Nutr Neurosci. 2019;22(8):596-606.

23. Sasaki T, Li W, Zaike $S$ et al. Antioxidant lignoids from leaves of Ribes nigrum. Phytochemistry. 2013;95:333-340.

24. Wu X, Gu L, Prior LR et al. Characterization of anthocyanins and proanthocyanidins in some cultivars of Ribes, Aronia, and Sambucus and their antioxidant capacity. J Agric Food Chem. 2004;52(26):7846-7856

25. Ghosh D, McGhie TK, Zhang J et al. Effects of anthocyanins and other phenolics of boysenberry and blackcurrant as inhibitors of oxidative stress and damage to cellular DNA in SH-SY5Y and HL-60 cells. J Sci Food Agric. 2006;86:678-686.

26. Dalgård C, Christiansen L, Jonung T et al. No influence of increased intake of orange and blackcurrant juices and dietary amounts of vitamin $\mathrm{E}$ on paraoxonase-1 activity in patients with peripheral arterial disease. Eur J Nutr. 2007;46(6):354-363.

27. Dalgård C, Nielsen F, Morrow JD et al. Supplementation with orange and blackcurrant juice, but not vitamin E, improves inflammatory markers in patients with peripheral arterial disease. Br J Nutr. 2009;101(2):263-269.

28. Li L, Zhao X, Ma L et al. Experiment study of blackcurrant on vascular endothelial cells injury induced by hydrogen peroxide (in Chinese). Wei Sheng Yan Jiu. 2009;38(5):592-5.

29. Lyall KA, Hurst SM, Cooney J et al. Short-term blackcurrant extract consumption modulates exercise-induced oxidative stress and lipopolysaccharidestimulated inflammatory responses. Am J Physiol Regul Integr Comp Physiol. 2009;297(1):R70-81.

30. Salobir J, Zontar TP, Levart A et al. The comparison of black currant juice and vitamin $E$ for the prevention of oxidative stress. Int J Vitam Nutr Res. 2010 Jan;80(1):5-11.

31. Rosenblat M, Volkova N, Attias J et al. Consumption of polyphenolic-rich beverages (mostly pomegranate and black currant juices) by healthy subjects for a short term increased serum antioxidant status, and the serum's ability to attenuate macrophage cholesterol accumulation. Food Funct. 2010;1(1):99-109.

32. Gođevac $D$, Tešević $V$, Vajs $V$ et al. Chemical composition of currant seed extracts and their protective effect on human lymphocytes DNA. J Food Sci. 2012;77(7):C779-783.

33. Tabart J, Franck T, Kevers C et al. Antioxidant and anti-inflammatory activities of Ribes nigrum extracts. Food Chemistry. 2012;131(4):1116-1122.

34. Huebbe P, Giller K, Pascual-Teresa S et al. Effects of blackcurrant-based juice on atherosclerosis-related biomarkers in cultured macrophages and in human subjects after consumption of a highenergy meal. Br J Nutr. 2012;108(2):234244.

35. Ambrożewicz E, Augustyniak A, Gęgotek A. Black-currant protection against oxidative stress formation. J Toxicol Environ Health A. 2013;76(23):1293-1306.

36. Khan F, Ray S, Craigie MA et al. Lowering of oxidative stress improves endothelial function in healthy subjects with habitually low intake of fruit and vegetables: A randomized controlled trial of antioxidantand polyphenol-rich blackcurrant juice. Free Radic Biol Med. 2014;72:232-237.

37. Miladinović B, Kostić M, Šavikin K et al. Chemical profile and antioxidative and antimicrobial activity of juices and extracts of 4 black currants varieties (Ribes nigrum L.). J Food Sci. 2014;79(3):C301-309.

38. Yamamoto A, Nakashima K, Kawamorita S et al. Protective effects of raw and cooked blackcurrant extract on DNA damage induced by hydrogen peroxide in human lymphoblastoid cells. Pharm Biol. 2014 Jun;52(6):782-788.

39. Bonarska-Kujawa D, Cyboran S, Żyłka R et al. Biological activity of blackcurrant extracts (Ribes nigrum L.) in relation to erythrocyte membranes. Biomed Res Int. 2014:783059.

40. Lee SG, Kim B, Yang Y et al. Berry anthocyanins suppress the expression and secretion of proinflammatory mediators in macrophages by inhibiting nuclear translocation of NF-KB independent of NRF2-mediated mechanism. J Nutr Biochem. 2014;25(4):404-411.

41. Strugala P, Dudra A, Gabrielska J. Activity of blackcurrant and chokeberry extracts and two major cyanidin glycosides against lipid membrane oxidation and their binding properties to albumin. Acta Poloniae Pharmaceutica. 2017;74(2):679-687.

42. Yamamoto A, Hirouchi T, Kawamorita S et al. Radioprotective activity of blackcurrant extract evaluated by in vitro micronucleus and gene mutation assays in TK6 human lymphoblastoid cells. Genes Environ. 2017 Sep 1;39:22.

43. Li L, Hwang E, Ngo HTT. Ribes nigrum L. Prevents UVB-mediated Photoaging in Human Dermal Fibroblasts: Potential Antioxidant and Antiinflammatory Activity. Photochemistry and Photobiology. 2018; 94(5):1032-1039.

44. Raudsepp P, Koskar J, Anton D. Antibacterial and antioxidative properties of different parts of garden rhubarb, blackcurrant, chokeberry and blue honeysuckle. J Sci Food Agric. 2019;99(5):2311-2320.

45. Zheng J, Yang B, Ruusunen $V$ et al. Compositional Differences of Phenolic Compounds between Black Currant (Ribes nigrum L.) Cultivars and Their Response to Latitude and Weather Conditions. J Agric Food Chem. 2012;60:6581-6593.

46. Vagiri M, Ekholm A, Öberg E et al. Phenols and ascorbic acid in black currant (Ribes nigrum L.): Variation due to genotype, location and year. J Agric Food Chem. 2013;61:9298-9306. 